\title{
Accumulation of algal pigments and live planktonic diatoms in aphotic sediments during the spring bloom in the transition zone of the North and Baltic Seas
}

\author{
Jørgen L. S. Hansen*, Alf B. Josefson \\ National Environmental Research Institute, 4000 Roskilde, Denmark
}

\begin{abstract}
The sediment contents of algal pigments and live planktonic diatoms were measured in cores sampled at 6 stations with aphotic sediments at depths between 27 and $55 \mathrm{~m}$ located in the transition zone between the Baltic Sea and the Skagerrak. Five of the stations were sampled before and after the spring phytoplankton bloom in 2001 . Within the area, there was a highly significant increase after the bloom in the sediment content of viable planktonic diatoms, quantified by the dilution extinction method, and in the sediment content of the pigments chlorophyll $a$ and fucoxanthin. The composition of algal pigments as well as the number of germinable diatoms suggested that live pelagic diatoms were the source of almost the entire pool of chlorophyll $a$ in the sediment both before and after the spring bloom. In the northern Kattegat, Great Belt, Femer Belt and in the Arkona Sea, the pools of diatoms increased 10- to 100-fold during the spring bloom. In total, the sediment received between 0.3 and 4 million germinable units of pelagic diatoms $\mathrm{cm}^{-2}$. In terms of organic nitrogen, the enrichment of live diatoms in the sediment corresponded to on average $202 \%$ of the total spring bloom production, calculated from the pool of nitrate consumed in the water column during the spring bloom. A similar calculation based on the enrichment of the pigments chlorophyll $a$ and fucoxanthin indicated input corresponding to 24 and $64 \%$ respectively of the potential production during the spring bloom. There was considerable variation among stations; in the central Kattegat there was no detectable sedimentation of diatoms or pigments. Here, the pools of pigments and diatoms decreased during the spring bloom and the shape of the pigment profiles also indicated that these pools did not originate from a recent input. Other stations received twice as much diatom biomass than could be produced from the pool of inorganic nitrogen in the mixed layer before the bloom. It is hypothesized that the unequal distribution of the spring bloom sedimentation is a result of episodic sedimentation events in combination with advection of the water masses. The potentials of using sediment profiles of pigments to quantify spring bloom sedimentation are discussed.
\end{abstract}

KEY WORDS: Diatoms - Spring bloom - Benthic-pelagic coupling $\cdot$ Sediment $\cdot$ Chlorophyll a Fucoxanthin

Resale or republication not permitted without written consent of the publisher

\section{INTRODUCTION}

In most temperate waters the annual plankton succession starts with a distinct bloom of diatoms evolving quickly in the spring. In many areas the typical fate of most of this phytoplankton biomass is sedimentation out of the photic zone whereas only a minor fraction of the algae are processed within the planktonic foodweb (Smetacek 1980, 1985, Olesen 1993, Kiørboe et al. 1994). Consequently, the material sinking out of the euphotic zone during and after the spring bloom is similar in composition to the suspended particles in the water column. In the annual sedimentation cycle, the timing of spring bloom sedimentation is almost always 
signalled by a distinct enrichment of fresh phytoplankton material in the downward flux. This is seen in sediment trap studies, in which the elemental composition of material caught during the spring bloom period shows lower ratios between carbon and nitrogen and between carbon and chlorophyll than during the rest of the year (Davis \& Payne 1984, Wassmann 1991, Olesen \& Lundsgaard 1995). In quantitative terms, spring bloom sedimentation is also a distinct phenomenon, as sedimentation during this relatively short period may account for 10 to $30 \%$ of total annual sedimentation (Wassmann 1991). The presence of intact and viable cells in the settling material is another characteristic of the flux associated with diatom blooms (Passow 1991, Riebesell 1991, Olesen 1993). On some occasions, blooms undergo mass sedimentation as a result of aggregate formation, and almost the entire biomass settles out of the photic zone within a few days (Alldredge \& Gotschalk 1989, Olesen 1993, Tiselius \& Kuylenstierna 1996, Kristiansen et al. 2001). Whether the spring bloom settles out in the form of fresh algal material or as degraded material may also vary from year to year depending on the abundance and composition of the zooplankton (Reigstad et al. 2000). Other authors have suggested that mechanisms such as the ability of the phytoplankton to form fast-settling aggregates determine the efficiency, and thus the fraction, of phytoplankton biomass that escapes degradation in the plankton and settles out (Tallberg \& Heiskanen 1998).

Benthic ecologists have traditionally paid attention to the spring bloom sedimentation event due to its quantitative role in supplying organic matter to the benthic food-web (Graf et al. 1982, Kanneworff \& Christensen 1986, Trimmer et al. 1999). It has also been presumed that the food quality of the spring bloom input is particularly high through enrichment with fresh phytodetritus and diatoms (Davis \& Payne 1984, Lopez \& Levinton 1987). To understand the functioning of the benthic ecosystem, it is highly important to know the pelagic input at a reasonable spatial and temporal resolution. The question of how well flux measurements using sediment traps in the water-column describe the amount and composition of organic matter being deposited in sediments during the spring bloom period is difficult to answer. The accuracy of sediment traps has been debated (Baker et al. 1988). Resuspension events may obscure measurements of net sedimentation rates-especially if the traps are deployed close to the sediment (Davis \& Payne 1984). Advection of water masses and degradation are other potential mechanisms that can result in a spatial mismatch between the flux measured in the water column and the size of the input actually received by the sediment below. Thus, the task of extrapolating from watercolumn output to sediment input may involve several problems. Comparative studies of fluxes of organic matter through the water column and input to the sediment are rare in the literature, and their data show large discrepancies (Graf et al. 1983, Rydberg et al. 1990). The input of organic matter is inherently difficult to measure in the sediment, as the input is typically less than a small percentage of the total pool of organic carbon in the surface sediment. On the other hand, the spring bloom input is qualitatively evident as a pronounced enrichment of pigments in surface sediments, and chlorophyll has been used as a marker of the spring bloom input (e.g. Kanneworff \& Christensen 1986). No direct attempts have been made directly to quantify the input from the accumulation during the spring bloom. It has been reported that the pool of chlorophyll in the sediment is relatively labile, with decay rates of, on average, $0.03 \mathrm{~d}^{-1}$ (Sun et al. 1991). The source of chlorophyll in the sediment has been debated, and it has been suggested that there exists more than 1 pool of chlorophyll and that some of the chlorophyll in the sediment is unrelated to fresh phytodetritus (Sun et al. 1991). Hansen \& Josefson (2001) found that the pools of chlorophyll in aphotic sediments could be explained by the presence of live pelagic diatoms and that the sizes of both parameters corresponded well with the expected size of the spring bloom sedimentation in their study area. In agreement with other recent studies (Itakura et al. 1997, Lewis et al. 1999), Hansen \& Josefson (2001) concluded that diatoms buried in the sediment have very slow degradation rates. The finding of Hansen \& Josefson (2001) has led to the hypothesis that the enrichment of diatoms can generally be used to quantify how much of the new production of the spring bloom is channelled directly into the benthic ecosystem. In this study, we have tried to test this hypothesis and calculate the size of the spring bloom sedimentation by measuring the accumulation of pelagic diatoms and algal pigments. We recorded changes in the sediment content of viable diatoms, chlorophyll $a$ and the diatom-specific pigment fucoxanthin before and after the spring bloom at 5 stations located in the transition zone between the North Sea/Skagerrak and the Baltic Sea. We compare this enrichment figure with the potential spring-bloom sedimentation, estimated from the pre-bloom available pool of nitrate in the area.

\section{MATERIALS AND METHODS}

Study area. This study was carried out at 6 stations (Fig. 1, see also Table 1), of which 5 were sampled before and after the spring bloom 2001, while 1 station (P6) was sampled only after the spring bloom. The stations are located in the western Baltic Sea, the Great 


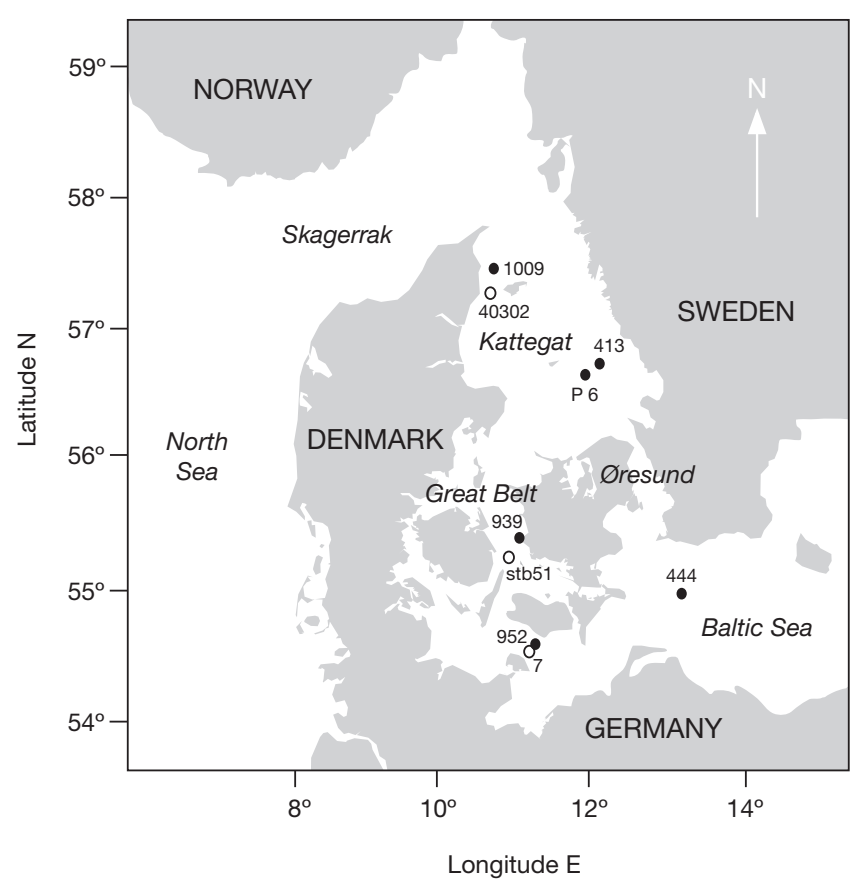

Fig. 1. Location of stations within study area. (•) Stations used for sediment sampling as well as hydrographic measurements before the spring bloom; (O) data from Stns 40302, stb51 and 7 used to characterize hydrographic conditions during spring bloom at Stns 1009, 939 and 952 respectively

Belt and in the Kattegat. This area is in the transition zone where high-saline waters from the central North Sea and North Atlantic mix with low-saline waters from the Baltic Sea. The surface salinity gradually declines from ca. 30 PSU at the northernmost station (Stn 1009) to a level of ca. 7 PSU in the Arkona Sea (Stn 444). At all stations, there is usually a pycnocline, separating a mixed low-saline surface layer from highsaline bottom water. In the western Baltic Sea (Stns 952, 444) a thermocline is established in early spring, and this determines the thickness of the mixed layer during the spring bloom. At all sites, the bottom consists of sandy mud. The stations have been part of the Danish National Monitoring Program since 1975 and are presently being sampled 5 times annually. The measurements include temperature, salinity, dissolved oxygen, inorganic nutrients, and chlorophyll $a$. Benthic macrofauna is being sampled annually at all stations except Stn 1009. In addition, the Swedish authorities monitor Stns 413 and 444 monthly, and hydrographic data from stations close to Stns 1009 and 939 are sampled weekly or monthly by local authorities. Our study comprised 3 cruises on the RV 'Gunnar Thornson' and RV 'Havternen' in February, April and May 2001. We used hydrographic data from our cruise in February 2001 as well as data from Swedish, German and local authorities to determine the timing of the spring bloom and to calculate the amount of inorganic nitrogen being turned over during the spring bloom 2001.

Sampling of sediment cores. Triplicate or duplicate sediment cores were sampled from Stns 1009, 413, 939, 952 and 444 on 2 occasions in 2001; the first sampling was conducted in February. Stations 939, 952 and 444 were sampled again in late April and Stns 1009 and 413 were sampled again in May together with 5 replicates from Stn P6 (Table 1). The sediment cores were sampled with a Haps-corer (frame-supported bottom corer) with an internal diameter, $\varnothing$, of $13.5 \mathrm{~cm}$ (Kanneworff \& Nicolaisen 1973). From each core, a subcore was sampled with a transparent plexiglass tube with an internal diameter of $4.5 \mathrm{~cm}$. The transparent tubes allowed inspection of the core at the actual location, and only cores that looked fairly undisturbed were used. The cores were sectioned in the following depth intervals: $0-1,1-2,2-3,3-5,5-8,8-12$ and $12-16 \mathrm{~cm}$. Each slice was homogenized, and triplicate samples of 1 to $3 \mathrm{~g}$ of wet sediment were put into closed vials and stored at $5^{\circ} \mathrm{C}$ in the dark.

For HPLC analysis of pigments in sediment samples, ca. $1 \mathrm{~g}$ of freeze-dried and crushed sediments (as recommended by Buffan-Dubau \& Carman 2000) were extracted in $10 \mathrm{ml}$ cold $100 \%$ acetone in the refrigerator for $24 \mathrm{~h}$. Samples were shaked in a minishaker and, after 4 to $5 \mathrm{~h}$, ultra-sonicated while cooling for $15 \mathrm{~min}$. Before analysis, the extracts were filtered through a $0.5 \mu \mathrm{m}, 25 \mathrm{~mm}$ filter (CAMEO $25 \mathrm{GF}$, Frisinette), and 1 $\mathrm{ml}$ was transferred to a new glass and mixed with $0.3 \mathrm{ml}$ of water (HPLC-grade). Of this, $0.7 \mathrm{ml}$ was transferred to a dark glass. Samples were kept $\operatorname{cool}\left(8^{\circ} \mathrm{C}\right)$ and in dim light during the whole procedure.

Pigment concentrations were determined by HPLC using ion-pairing reverse-phase high-performance liquid chromatography (Mantoura \& Llewellyn 1983). The HPLC system used was a 2-pump Gilson system with a UV/VIS Gilson 119 detector. The column used was a $5 \mu \mathrm{m}$ ODS (150 $\mathrm{mm} \times 4.6 \mathrm{~mm}$ i.d.) packed with Develosil C18-5. Detection was performed at a wavelength of $449 \mathrm{~nm}$ for fucoxanthin and of $662 \mathrm{~nm}$ for chlorophyll a. Two mobile phases (HPLC grade, A and B) were used: (A) $75 \%$ acetone and $25 \%$ Milli-Q water; (B) $80 \%$ acetone and $20 \%$ methanol. After injection of $100 \mu$ l extract per sample, a gradient programme ramped from $100 \mathrm{~A}$ to $50 \%$ each of $\mathrm{A}$ and $\mathrm{B}$ after $10 \mathrm{~min}$, and to $100 \%$ B after 20 min. This concentration was maintained for $5 \mathrm{~min}$, and then returned to $100 \%$ A over 2 min. Finally this concentration was maintained for $8 \mathrm{~min}$. Total analysis time was $35 \mathrm{~min}$. Flow rate was 0.85 $\mathrm{ml} \mathrm{min}{ }^{-1}$. Identification of chlorophyll $\mathrm{a}$ and fucoxanthin was confirmed by co-elution with authentic standards from the Danish Hydraulic Institute (DHI), and a 4-point calibration curve was used to convert peak areas to amount of pigment. Pigment concentrations by HPLC 
are reported in $\mu \mathrm{g} \mathrm{g}^{-1}$ dry weight. Depth-integrated pools of pigments are the total volume-specific concentration calculated with water content and assuming a density of dry sediment of $2.5 \mathrm{~g} \mathrm{~cm}^{-3}$.

Germination of viable diatoms. The abundance of viable diatoms was determined using the dilution extinction method. Sediment samples from replicate cores from 4 depth intervals $(0-1,1-2,2-3$ and 5-8 m) were selected for the germination experiment, which followed the principles described in Itakura et al. (1997) and Hansen \& Josefson (2001). In short, the procedure included the following steps: the samples were resuspended in $10 \mathrm{ml} 0.2 \mu \mathrm{m}$-filtered seawater, from which we made a dilution series of decadal steps with a concentration of sediment slurry going from $10^{-2}$ to $10^{-7}$. From each dilution, $1 \mathrm{ml}$ in 5 replicates was added to $1 \mathrm{ml}$ of B1 growth medium (Hansen 1989) and inoculated in individual wells on a 24 -well multi-dish cell culture plate (Nunc). The salinity of the growth media and filtered seawater were adjusted to match the salinity of the bottom water at the respective stations. After 10 to 14 d inoculation, each well was examined under an inverted microscope (Utermöhl 1958) to record the number of distinguishable diatom species. The most probable number (MPN) of germinable diatoms (germinable units, GU) were obtained by the criterion growth/non-growth of pelagic diatoms as well as individually for species belonging to the 4 dominant genera: Thalassiosira, Chaetoceros, Skeletonema and Leptocylindrus. After the first inspection the plates were re-inoculated for another 2 to $5 \mathrm{~d}$ to check if more wells appeared to hold germinable diatoms.
Analysis of cell-specific pigment contents. To compare the abundance of diatoms in terms of MPN with that expected from the sediment pigment content, we determined the cell-specific content of pigments of 4 cultivated diatom species, Thalassiosira sp., Chaetoceros socialis, Skeletonema costatum, and Leptocylindrus sp. These species had all been isolated from sediment in the Øresund $\left(12^{\circ} 41^{\prime} 65^{\prime \prime} \mathrm{E}, 55^{\circ} 58^{\prime} 05^{\prime \prime} \mathrm{N}\right.$, Fig. 1) in March 2000, and were grown under the same conditions as in the germination experiment. When the cultures were at the exponential growth phase, we sampled them for measurements of the pigments chlorophyll $a$ and fucoxanthin and for cell counting using the inverted microscope technique. Samples for pigments were filtered onto GF/C filters, extracted in acetone, and the concentration of the pigments was analyzed using HPLC as described above.

\section{RESULTS}

\section{Hydrography}

At the time of the first sampling in February 2001, the spring bloom had not yet started (Ærtebjerg 2001); the concentration of chlorophyll a was low, at between 0.2 and $1.6 \mu \mathrm{gl}^{-1}$ (data not shown), and the surface nitrate concentration was high throughout the area, varying between $113 \mu \mathrm{g} \mathrm{N}^{-1}$ at Stn 1009 to $27 \mu \mathrm{g} \mathrm{N}^{-1}$ at Stn 444 (Table 1). The exact timing of the spring bloom peak at the stations is unknown. However, in the middle of March, Swedish measurements showed

Table 1. Sampling dates before and after spring bloom 2001, physical characteristics and concentration of nitrate at stations in the study area. Water content of the sediment was measured in samples from February by freeze-drying. Depth of the mixed layer was determined by a halocline at Stns 1009, 413 and 939 and by a thermocline at Stns 952 and 444 . Average surface concentration $(0$ to $10 \mathrm{~m}$ ) of nitrate was measured during the first sampling cruise; available pool of nitrogen in the mixed layers is calculated as product of mixed layer depth times average concentration in upper $10 \mathrm{~m}$. -: no data

\begin{tabular}{|c|c|c|c|c|c|c|}
\hline & $\begin{array}{c}\text { Stn } 1009 \\
57^{\circ} 26.13^{\prime} \mathrm{N}, \\
10^{\circ} 42.66^{\prime} \mathrm{E}\end{array}$ & $\begin{array}{c}\text { Stn } 413 \\
56^{\circ} 40.00^{\prime} \mathrm{N} \\
12^{\circ} 07.00^{\prime} \mathrm{E}\end{array}$ & $\begin{array}{c}\text { Stn P6 } \\
56^{\circ} 34.37^{\prime} \mathrm{N}, \\
11^{\circ} 54.96^{\prime} \mathrm{E}\end{array}$ & $\begin{array}{c}\text { Stn } 939 \\
55^{\circ} 22.60^{\prime} \mathrm{N} \\
11^{\circ} 00.00^{\prime} \mathrm{E}\end{array}$ & $\begin{array}{c}\text { Stn } 952 \\
54^{\circ} 34.20^{\prime} \mathrm{N} \\
11^{\circ} 20.00^{\prime} \mathrm{E}\end{array}$ & $\begin{array}{c}\text { Stn } 444 \\
55^{\circ} 00.00^{\prime} \mathrm{N}, \\
13^{\circ} 18.00^{\prime} \mathrm{E}\end{array}$ \\
\hline First sampling & 6 Feb & 5 Feb & - & $13 \mathrm{Feb}$ & $14 \mathrm{Feb}$ & $14 \mathrm{Feb}$ \\
\hline Second sampling & 15 May & 14 May & 14 May & $23 \mathrm{Apr}$ & 22 Apr & $22 \mathrm{Apr}$ \\
\hline Water depth (m) & 27 & 55 & 32 & 38 & 27 & 45 \\
\hline Water content of sediment (\%) & 50 & 66 & - & 34 & 37 & 70 \\
\hline $\begin{array}{l}\text { Depth of mixed layer during } \\
\text { spring bloom }(\mathrm{m})\end{array}$ & $15^{\mathrm{a}}$ & 15 & 15 & $8^{\mathrm{b}}$ & $11^{\mathrm{b}}$ & 10 \\
\hline $\begin{array}{l}\text { Conc. nitrate-N, average } 0-10 \mathrm{~m} \text {, } \\
\left(\mu \mathrm{g} \mathrm{l}^{-1}\right)\end{array}$ & 113 & 58.5 & - & 90.0 & 67.5 & 27.0 \\
\hline $\begin{array}{l}\text { Pool of nitrate-N in mixed layer, } \\
\left(\mathrm{g} \mathrm{N} \mathrm{m}^{-2}\right)\end{array}$ & 1.7 & 0.88 & - & 0.72 & 0.74 & 0.27 \\
\hline
\end{tabular}


Table 2. Sediment pool of chlorophyll a $(\mathrm{chl} a)$, and fucoxanthin integrated over the top $5 \mathrm{~cm} \pm \mathrm{SD}$, and germinable diatom units, GU (in billions) integrated over the top $3 \mathrm{~cm}$ of sediment before and after the spring bloom (SB). Inputs per $\mathrm{m}^{2}$ are calculated as differences between post-bloom and pre-bloom situations. MPN: most probable number

\begin{tabular}{|c|c|c|c|c|c|c|}
\hline Parameter & Stn 1009 & Stn 413 & Stn 939 & Stn 952 & Stn 444 & Average \\
\hline \multicolumn{7}{|c|}{ Chl a $\left(\mathrm{mg} \mathrm{m}^{-2}\right)$} \\
\hline Before SB & $18.6 \pm 3.4$ & 13.2 & $6.1 \pm 0.79$ & $10.6 \pm 3.7$ & $14.7 \pm 1.5$ & $12.6 \pm 7.6$ \\
\hline After SB & $22.5 \pm 9.3$ & $12.5 \pm 1.4$ & $9.0 \pm 0.86$ & $39.2 \pm 9.0$ & $34.3 \pm 2.37$ & $23.7 \pm 14.4$ \\
\hline Input & 4.3 & -0.7 & 2.9 & 28.6 & 19.6 & 10.9 \\
\hline \multicolumn{7}{|c|}{ Fucoxanthin before $\left(\mathrm{mg} \mathrm{m}^{-2}\right)$} \\
\hline Before SB & $16.7 \pm 2.4$ & 8.5 & $0^{\mathrm{a}}$ & $7.99 \pm 0.11$ & $33.3 \pm 6.25$ & 13.3 \\
\hline After SB & $28.7 \pm 12.1$ & $8.28 \pm 2.19$ & $5.9 \pm 1.9$ & $49 \pm 13.2$ & $122 \pm 28.7$ & $42.3 \pm 59$ \\
\hline Input & 11.7 & -0.22 & 5.9 & 40.6 & 88.7 & 29 \\
\hline \multicolumn{7}{|c|}{ Diatoms, GU $\left(\mathrm{MPN} \times 10^{9} \mathrm{~m}^{-2}\right)$} \\
\hline Before SB & $1.4 \pm 0.10$ & $2.9 \pm 0.18$ & $0.091 \pm 0.033$ & $1.6 \pm 2.1$ & $1.0 \pm 0.68$ & $1.4 \pm 2.2$ \\
\hline After SB & $22 \pm 19$ & $0.084 \pm 0.052$ & $2.5 \pm 1.7$ & $10 \pm 7.1$ & $29 \pm 19$ & $12 \pm 15$ \\
\hline Input & 20 & -2.0 & 2.4 & 8.8 & 28 & 11 \\
\hline
\end{tabular}

that nitrate had dropped to less than $5 \mu \mathrm{g} \mathrm{N} \mathrm{l^{-1 }}$ in the mixed layer in the eastern Kattegat, including Stn 413 (Thorstensson 2001). German measurements close to Stns 444 and 952 showed that surface nitrate concentration was reduced to less than $3 \mu \mathrm{g} \mathrm{N} \mathrm{l}^{-1}$ in late March (Anonymous 2001). Hydrographic measurements in the Great Belt, close to Stn 939, showed that nitrate and silicate declined fast in the middle of March, and shortly afterwards the concentration of chlorophyll a peaked at $6 \mu \mathrm{g} \mathrm{l}^{-1}$ (Fyns Amt 2002). The same pattern was seen at a station close to Stn 1009 (Bråten \& Jensen 2002). Altogether, the dynamics of nutrients and chlorophyll a indicated that the spring bloom had peaked and finished during March over the entire area, i.e. 1 to 2 mo before the second sampling cruise.

Before the spring bloom (first cruise), the salinity followed the spatial pattern normal for that area (Ærtebjerg 2001), and CTD profiles showed the presence of a halocline at all stations (data not shown). In the Kattegat (Stns 1009 and 413), the halocline was very strong and situated at 15 to $16 \mathrm{~m}$ depth. In the Great Belt (Stn 939) and further south (Stn 952), the halocline was less distinct at 8 to $10 \mathrm{~m}$ depth, and at Stn 444 the mixed layer extended down to the halocline at $35 \mathrm{~m}$ depth. After the spring bloom, in May, Swedish monitoring data (Thorstensson 2001) showed that the upper mixed layer was still $15 \mathrm{~m}$ in the Kattegat at Stn 413, but at Stn 444 the mixed layer had narrowed due to a thermocline established at $10 \mathrm{~m}$ depth (Table 1). German monitoring data (Anonymous 2001) showed that the depth of the surface mixed layer was about $11 \mathrm{~m}$ in early May at a station close to Stn 952. In the Great Belt (near Stn 939) the mixed layer varied between 7 and $10 \mathrm{~m}$ during March; this was also the layer from which nitrate became depleted during the spring bloom (Fyns Amt 2002). The total pool of nitrate consumed by the spring bloom at the individual stations was calculated from the initial concentrations (first cruise) times the depth of the mixed zone during the spring bloom as described above, and is expressed in terms of $g$ nitrate$\mathrm{N} \mathrm{m}^{-2}$ (Table 1).

\section{Sediment data}

All cores consisted of fine-grained muddy sediment. The water content decreased with increasing core depth, ranging between 79 and $37 \%$ in the surface sediment and between 61 and $20 \%$ at $10 \mathrm{~cm}$ depth (see also Table 1). The colour of the sediment profiles from the first sampling indicated that the oxidized layer extended to at least $4 \mathrm{~cm}$. On the second sampling, the oxidized layers were more than $3 \mathrm{~cm}$ thick.

\section{Distribution of pigments and live planktonic diatoms in the sediment}

Before the spring bloom, the pigment content varied considerably between stations. Lowest content was at Stn 939 (6.1 mg chlorophyll a m²: Table 2), where fucoxanthin was below our detection limit of $0.04 \mu \mathrm{g} \mathrm{g}^{-1}$ dry wt in all samples (Table 2). The largest pools of chlorophyll $a$ and fucoxanthin were 14.7 and $33.3 \mathrm{mg}$ $\mathrm{m}^{-2}$, respectively, at $\mathrm{Stn} 444$. The number of pelagic diatoms (GU) in the top $3 \mathrm{~cm}$ of the sediment was on average $140000 \mathrm{~cm}^{-2}$, ranging between 9100 (Stn 939) and $287000 \mathrm{~cm}^{-2}$ (Stn 413). After the spring bloom, the concentrations of chlorophyll $a$ and fucoxanthin increased 
in the surface sediment, and this enrichment could generally be traced down to $3 \mathrm{~cm}$ depth in late April/early May (Figs. 2 \& 3). Fucoxanthin increased 2-to 6-fold at all stations except Stn 413, where the concentration of
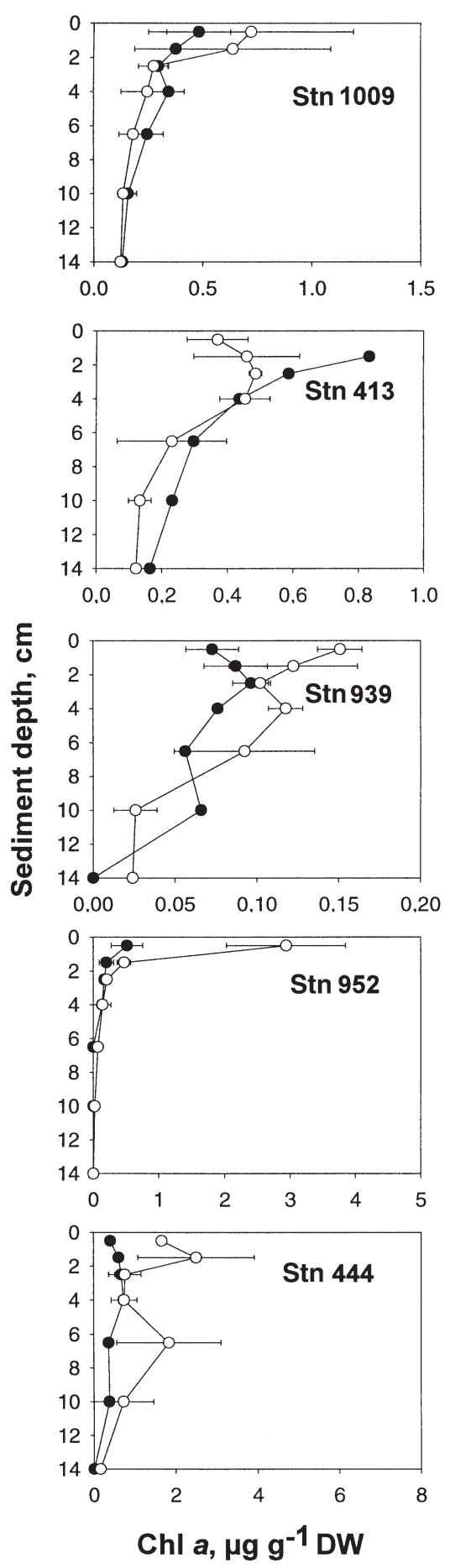

Fig. 2. Profiles of chlorophyll $a$ at each station before $\left(\boldsymbol{\theta}_{i} \pm \mathrm{SD}\right.$, $\mathrm{n}=2)$ and after $(\mathrm{O} ; \pm \mathrm{SD}, \mathrm{n}=3)$ spring bloom. Note different scales on $x$-axes both pigments decreased after the spring bloom (Fig. 2, Table 2). A paired $t$-test, comparing all data (logtransformed) before and after the spring bloom (station by station and depth by depth) for the upper $3 \mathrm{~cm}$ of the sediment revealed that enrichment of fucoxanthin was highly significant $(\mathrm{p}=0.000032, \mathrm{n}=25)$. A similar analysis of chlorophyll $a$ in the upper $3 \mathrm{~cm}$ of sediment also showed a significant increase during the spring bloom ( $p=0.0046, n=24)$. In the depth interval 3 to $5 \mathrm{~cm}$ and deeper, there was no significant change in either chlorophyll a $(\mathrm{p}=0.57, \mathrm{n}=24)$ or fucoxanthin $(\mathrm{p}=0.21, \mathrm{n}=10)$. The abundance of germinable diatoms increased more than 10-fold in the surface sediments during the spring bloom at Stns 1009, 939, 952 and 444 but, as with the pigments, it decreased at Stn 413 (Table 2). In the study area (including Stn 413) the enrichment of GU was highly significant in the upper $3 \mathrm{~cm}(\mathrm{p}=0.00033, \mathrm{n}=27$, paired $t$-test of logtransformed data). Applying the same test to the stations individually showed that the increase in GU was significant at Stns $1009(\mathrm{p}=0.005, \mathrm{n}=6), 939(\mathrm{p}=$ $0.00027, n=6), 952(p=0.013)$ and $444(p=0.005, n=6)$. At Stn 413 the abundance of diatoms decreased significantly ( $p=0.04, n=4)$. As Stn P6 was not sampled before the spring bloom, the input there cannot be determined. At this station, all 5 replicate cores were very low in chlorophyll $a$ and germinable diatoms (see Fig. 5) and fucoxanthin was below our detection limit in almost all samples. Even were the entire pools of pigments and GU at P6 due to input in 2001, this input would have been the lowest among the stations.

The profiles of pigments and diatoms generally followed an exponential decline with core depths both before and after the spring bloom. After the spring bloom, a recent input of diatom material on Stns 1009, 952 and 444 was evident from the profiles of fucoxanthin, which showed a much steeper exponential decline in the upper $5 \mathrm{~cm}$ than before the spring bloom (Fig. 4). At Stn 939, fucoxanthin was below the detection limit before the spring bloom, but after the spring bloom its decline with increasing depth was similar to that at the other stations (Fig. 4). The profiles of chlorophyll $a$ and germinable diatoms also became steeper at Stns 1009, 939, 952 and 444 (data not shown) with increasing depth. In contrast to the other stations, the pool of fucoxanthin became more evenly distributed, with increasing depth, at Stn 413. At the nearby Stn P6, the profiles of chlorophyll a followed the same exponential decline as at Stn 413, and the depth distribution of GU also conformed to that at Stn 413 (Fig. 5), although the total amount of germinable diatoms and pigments was lower at Stn P6.

The entire data set showed that the 2 pigments chlorophyll $a$ and fucoxanthin were very strongly correlated (Fig. 6). Generally the 2 pigments occurred at nearly the 

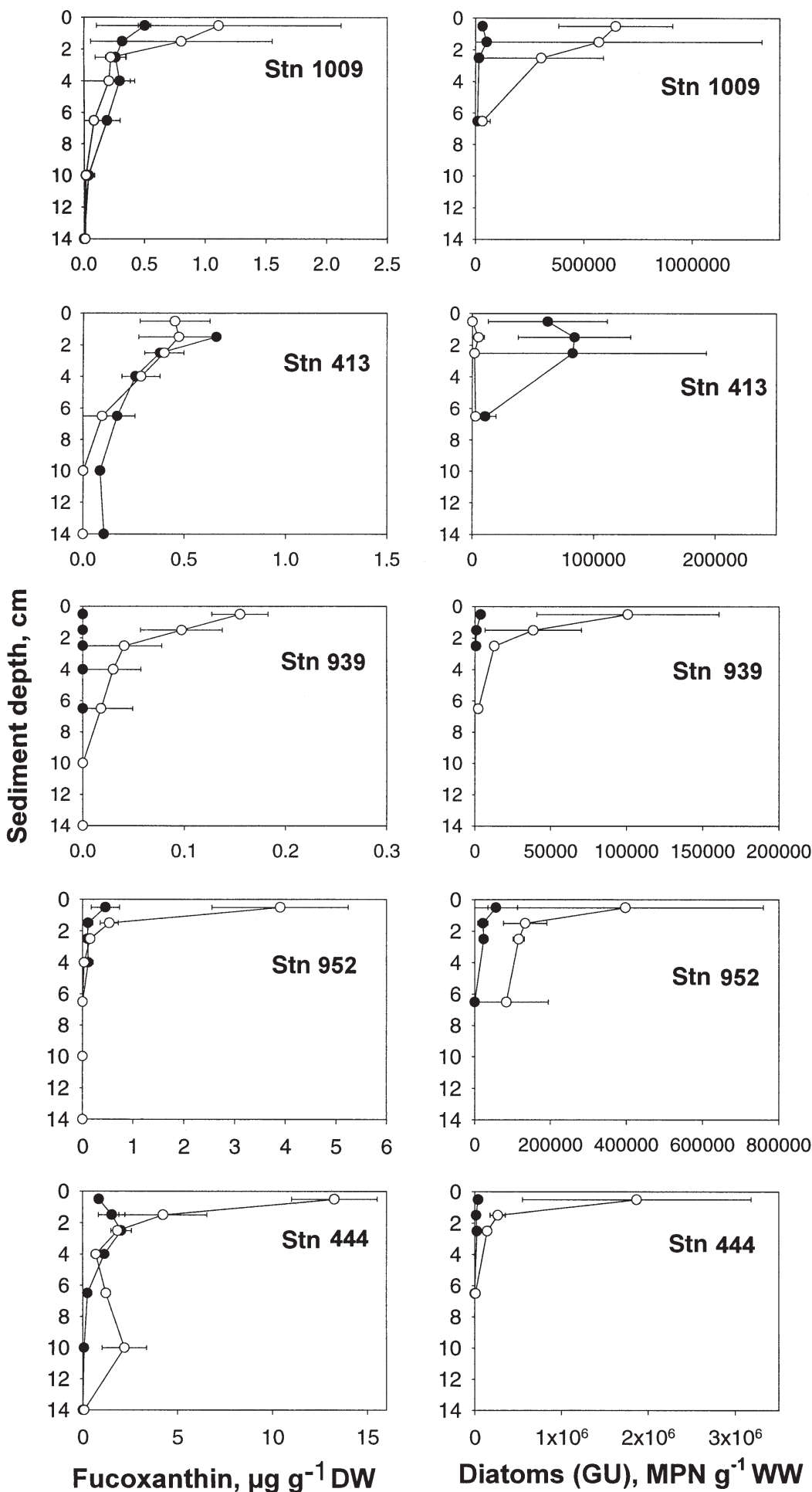

Fig. 3. Left graphs: profiles of fucoxanthin at each station before $(\bullet)$ and after $(0)$ spring bloom $( \pm \mathrm{SD})$; before spring bloom the concentration of fucoxanthin was below detection level at Stn 939; average data based on duplicate samples before and triplicate samples after the spring bloom. Right graphs: profiles of germinable units (GU) of planktonic diatoms expressed in terms of the most probable number (MPN) per $g$ wet sediment before $(\bullet)$ and after $(0)$ spring bloom $( \pm S D, n=2)$. Note different scales on $x$-axes same concentrations, although fucoxanthin concentrations were slightly higher. The average ratio between fucoxanthin and chlorophyll a was 1.2. The ratio between fucoxanthin and chlorophyll a was higher at Stn 444 than at the other stations (Table 2).

\section{Species composition}

Four genera of planktonic diatoms - Thalassiosira, Chaetoceros, Skeletonema, and Leptocylindrus - completely dominated the community in the sediments before the spring bloom (Fig. 7). There were no distinct differences between stations in the composition of genera, but different species of Thalassiosira and Chaetoceros seemed to dominate in the sediment in the Kattegat area and in the western Baltic, although not all of them could be identified to species (data not shown). After the spring bloom input, the community was dominated by the same genera, but the relative composition had changed. Before the spring bloom the community was dominated by the spore-forming genus Chaetoceros, while the non-sporeforming genus Skeletonema contributed with only $6 \%$. After the spring bloom the composition in the upper $3 \mathrm{~cm}$ of the sediment had shifted, as Skeletonema spp. comprised $48 \%$ of the total community (Fig. 7). In terms of taxonomic composition, Stn P6 differed from the other stations, as only $15 \%$ of the diatoms comprised Skeletonema spp. after the spring bloom.

The cell-specific contents of chlorophyll $a$ and fucoxanthin determined from 1 sampling of each of the of 4 monocultures were: Thalassiosira sp. $12.7 \mathrm{pg}$ fucoxanthin cell ${ }^{-1}$, 13.0 pg chlorophyll a cell ${ }^{-1}$; Chaetoceros sp. $=8.5 \mathrm{pg}$ fucoxanthin cell ${ }^{-1}, 5.7$ pg chlorophyll a cell ${ }^{-1}$; Skeletonema costatum = $2.6 \mathrm{pg}$ fucoxanthin cell $^{-1}, 1.1 \mathrm{pg}$ chlorophyll a cell ${ }^{-1}$; Leptocylindrus sp. $=17.3 \mathrm{pg}$ fucoxanthin cell ${ }^{-1}$ and $15.7 \mathrm{pg}$ chlorophyll $a$ $\mathrm{cell}^{-1}$. The average ratio of fucoxanthin and chlorophyll a was 1.15. Assuming that $1 \mathrm{GU}$ consisted of 1 diatom cell, we used these values of cell-specific content of fucoxanthin for each species to calculate a predicted concentration of fucoxanthin in the sediment from GU. As there were several species present of each of the genera Thalassiosira and Chaetoceros, we used the same value for all 

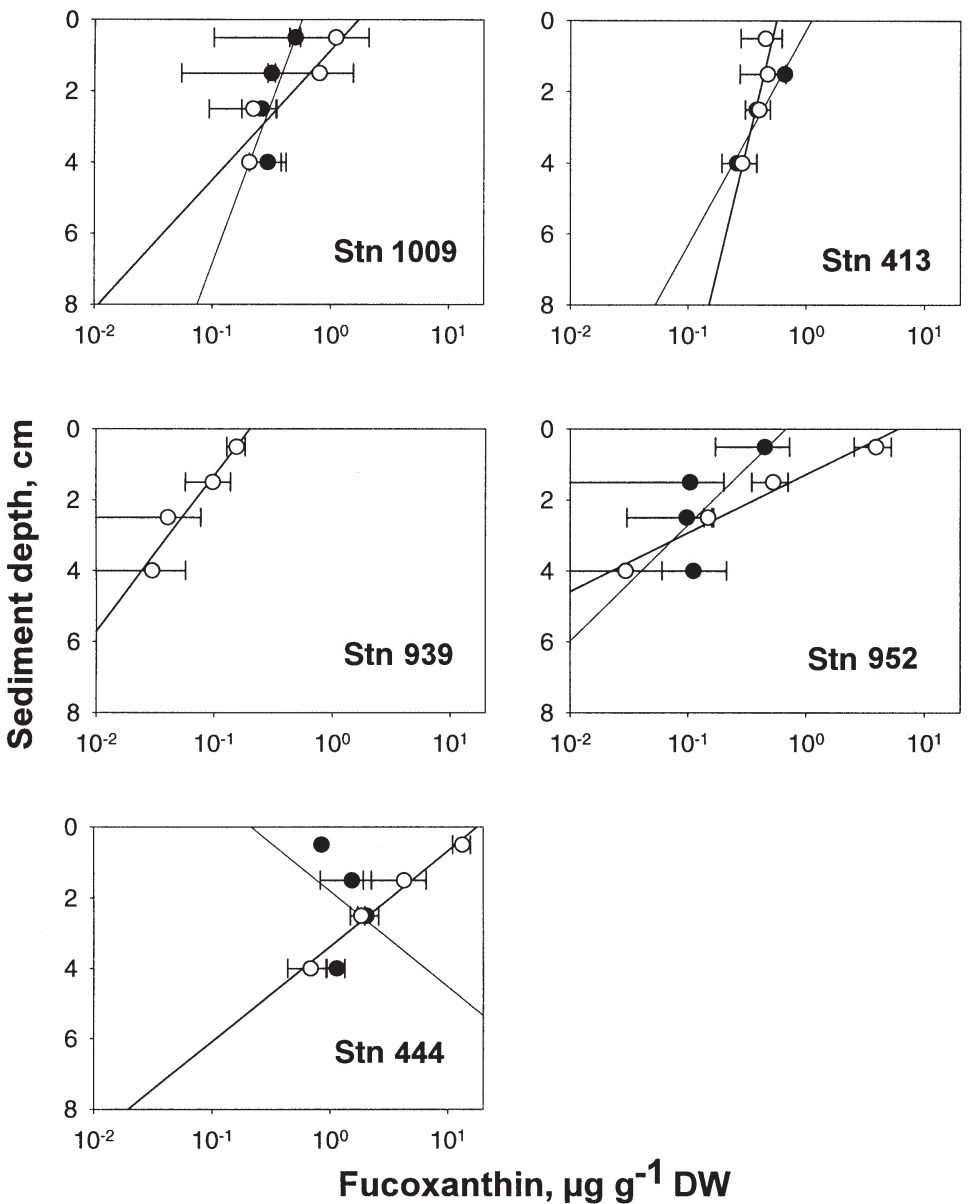

Fig. 4. Average concentration of fucoxanthin (log scale) vs sediment depth (data from 0 to $5 \mathrm{~cm}$ depth) before $(\bullet \pm \mathrm{SD}, \mathrm{n}=2)$ and after $(\mathrm{O} ; \pm \mathrm{SD}, \mathrm{n}=3)$ spring bloom. Slopes of regressions of log concentration vs depth before the spring bloom (SB) and after the spring bloom (SA) are as follows: $\mathrm{Stn}$ 1009: $\mathrm{SB}=-0.11, \mathrm{r}^{2}=0.56, \mathrm{SA}=-0.28, \mathrm{r}^{2}=0.84$. Stn 413: $\mathrm{SB}=-0.16, \mathrm{r}^{2}=0.95, \mathrm{SA}=-0.072, \mathrm{r}^{2}=0.83$. Stn 939: $\mathrm{SA}=-0.23$, $\mathrm{r}^{2}=0.93$. Stn 952: $\mathrm{SB}=-0.3, \mathrm{r}^{2}=0.48, \mathrm{SA}=-0.61, \mathrm{r}^{2}=0.98$. Stn 444 : $\mathrm{SB} 0.36, \mathrm{r}^{2}=0.08 \mathrm{SA}=-0.36 \mathrm{r}^{2}=0.98$. All data were below our detection limit for pre-bloom situation at Stn 939 species belonging to the same genus when these were roughly of the same cell size as those in our cultures. A few large but very rare species were excluded from this calculation. Considering all data there was a significant positive correlation between measured values of fucoxanthin and predicted values ( $\mathrm{p}<0.0001, \mathrm{n}=46$ ) (Fig. 8). However, before the spring bloom, the predicted values were poorly correlated with observed values due to measurements for Stn 444, where we found about $1 \mu^{-1}$ of fucoxanthin but few germinable diatoms. Omitting the data from Stn 444, the correlation between predicted and observed values was significant before the spring bloom $(\mathrm{p}=0.03, \mathrm{n}=16)$. After the spring bloom the correlation between predicted and observed concentrations of fucoxanthin was significant $(p=0.0014)$. The average ratio between predicted and measured values (following log transformation) was 1.1 when including all data except Stn 444 before the spring bloom $(\mathrm{n}=42)$.

\section{Nitrogen budgets}

The input of diatom biomass to the sediment during the spring bloom was calculated as the difference in the pool size of pigments and diatoms before and after the spring bloom in the top 0 to $5 \mathrm{~cm}$ of the sediments (Table 3). These values were converted into nitrogen equivalents by assuming that the ratio by weight of organic N/chlorophyll a was 8.7. This ratio corresponds to a carbon/ chlorophyll a ratio of 50, a value typical for that area during the spring bloom (Kiørboe

Table 3. (A) Input to sediment of diatom material in nitrogen-equivalents $\left(\mathrm{mg} \mathrm{N} \mathrm{m}^{-2}\right)$ calculated from the enrichment of chlorophyll $a(\mathrm{chl}$ a), fucoxanthin and viable diatoms at each station. Conversion factors used for chl $a$ and fucoxanthin (by weight) $=8.6$ and 7.5, respectively. Germinable diatom units (GU, in most probable numbers, MPN) converted to nitrogen equivalents for each species using species-specific content of fucoxanthin (described in 'Materials and methods') and further converted to nitrogen equivalents by the above factors of 8.6 and 7.5. (B) Enrichment of sediment in nitrogen equivalents as percentage of nitrate pool in the mixed layer before spring bloom (Table 1)

\begin{tabular}{|c|c|c|c|c|c|c|}
\hline & Stn 1009 & Stn 413 & Stn 939 & Stn 952 & Stn 444 & Average \\
\hline \multicolumn{7}{|l|}{ (A) Difference } \\
\hline Chl a $\left(\mathrm{mg} \mathrm{m}^{-2}\right)$ & 37 & 0 & 25.9 & 406 & 171 & 128 \\
\hline Fucoxanthin $\left(\mathrm{mg} \mathrm{m}^{-2}\right)$ & 88 & 0 & 56.6 & 500 & 662 & 250 \\
\hline GU $\left(\mathrm{MPN} \mathrm{m}^{-2}\right)$ & 1580 & 0 & 199 & 620 & 2171 & 877 \\
\hline \multicolumn{7}{|l|}{ (B) Relative input (\%) } \\
\hline Chl a & 2.2 & 0 & 3.5 & 54 & 63 & 24 \\
\hline Fucoxanthin & 5.2 & 0 & 7.8 & 68 & 245 & 64 \\
\hline Diatom units (GU) & 93 & 0 & 28 & 85 & 802 & 202 \\
\hline
\end{tabular}



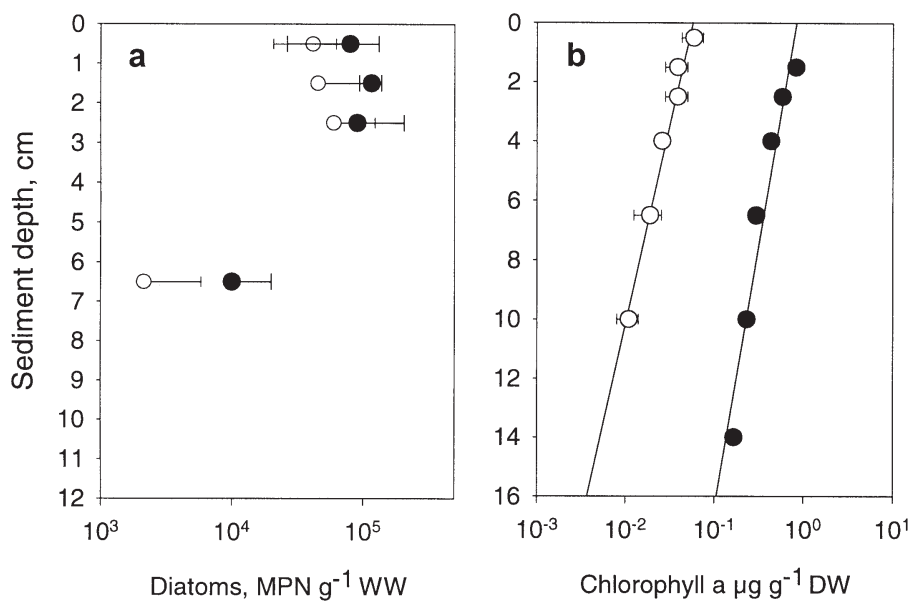

Fig. 5. (a) Profiles of germinable diatoms (GU) at Stn 413 before spring bloom $(\bullet ; \pm \mathrm{SD}, \mathrm{n}=2)$ and at Stn P6 after spring bloom $\left(\mathrm{O}_{;} \pm \mathrm{SD}, \mathrm{n}=5\right)$. (b) Profiles of chlorophyll $a$ at Stn 413 before spring bloom $(\bullet)$ and at Stn $\mathrm{P} 6$ after spring bloom $(\mathrm{O}$; $\pm \mathrm{SD}, \mathrm{n}=5$ ). Lines by linear regression

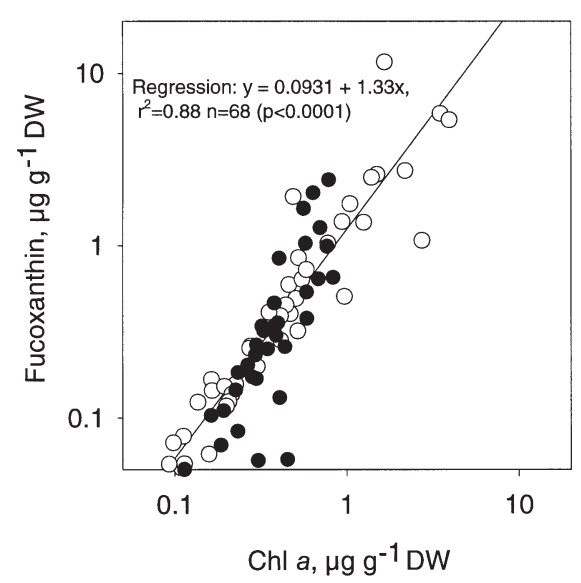

Fig. 6. Fucoxanthin vs chlorophyll a before (•) and after (O) spring bloom and regression of the entire data set $(p<$ 0.0001). Results of log-log regression slope $=1.33$, constant $=$ $0.0931, \mathrm{r}^{2}=0.88, \mathrm{n}=68$

et al. 1994, Olesen \& Lundsgaard 1995), combined with the Redfield-ratio between carbon and nitrogen. The ratio fucoxanthin/chlorophyll a was assumed to be 1.15 , the observed average in our 4 cultures. This ratio agrees with the average ratio of 1.2 observed in our sediment samples from the field. The numbers of germinable cells were converted into nitrogenequivalents using the predicted content of fucoxanthin and the above ratios between pigments and nitrogen. The input of diatom biomass, in terms of nitrogen equivalents, varies between locations. Comparison between the size of input and the pre-bloom available pool of inorganic nitrogen in the water column shows that Stn 444 received more diatom biomass than could be accounted for by production in
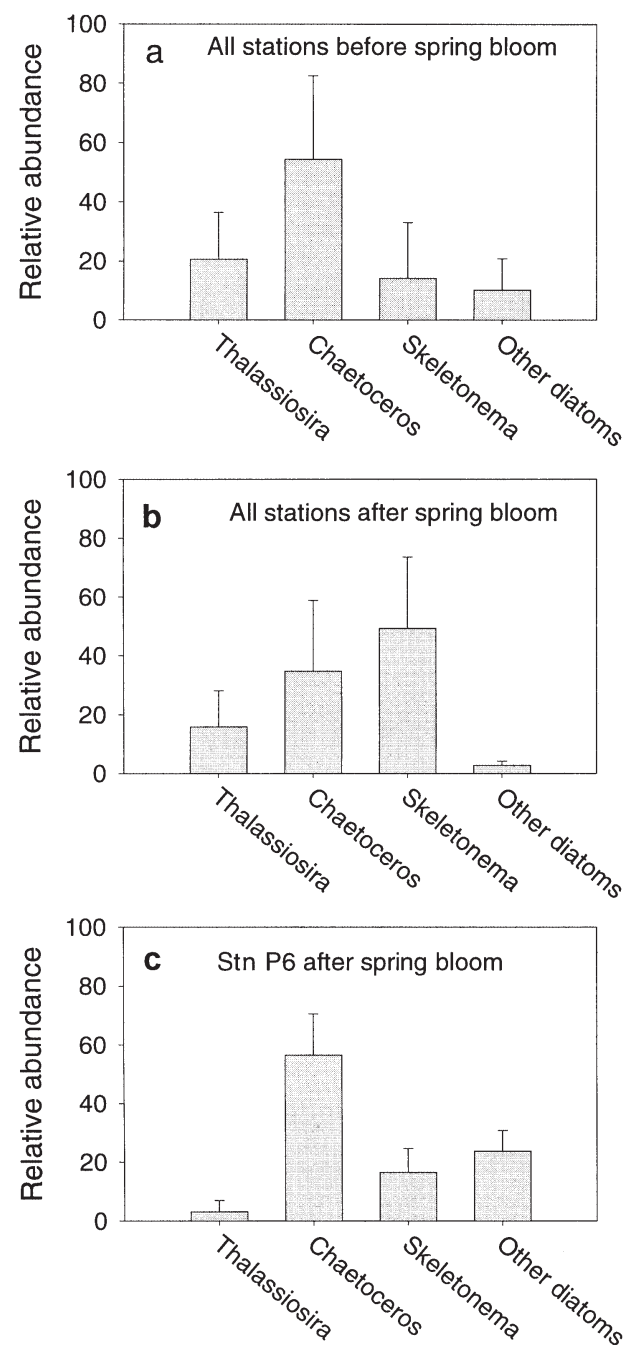

Fig. 7. Taxonomic composition of germinable diatoms (genus level) averaged over the top $3 \mathrm{~cm}$ sediment. (a) Average composition of diatoms for Stns 1009, 413, 939, 952 and 444 before spring bloom; error bars indicate standard deviations $(\mathrm{n}=30)$. (b) Average composition of diatoms for Stns 1009, 939, 952 and 444 after spring bloom $(\mathrm{n}=36)$; error bars indicate standard deviations (taxonomic composition was not determined at Stn 413 after the spring bloom). (c) Composition at Stn P6 after spring bloom $\pm \mathrm{SD}(\mathrm{n}=15)$

the overlying water column (Table 3). The other Stns, 1009, 939 and 952, received inputs of 2.2 to $93 \%$, while there was no input at Stn 413.

\section{DISCUSSION}

It has long been known that planktonic diatoms are capable of surviving very long periods under conditions prevailing in sediments in the sea (Smayda \& Mitchell-Innes 1974) and that live planktonic diatoms can be found in aphotic sediments (Garrison 1981). In 


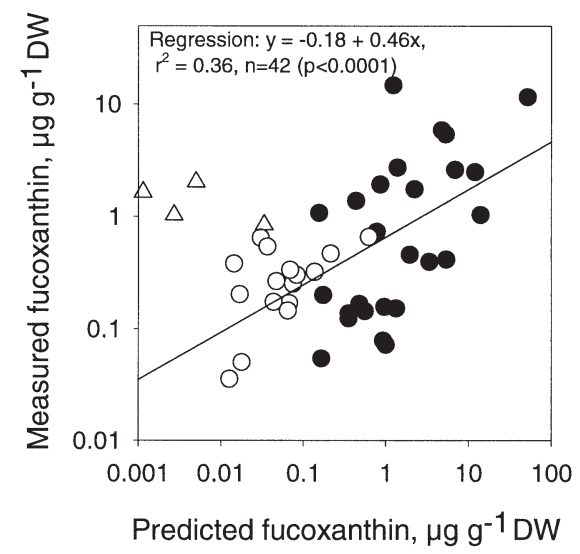

Fig. 8. Measured values of fucoxanthin concentrations vs fucoxanthin concentrations predicted from expected fucoxanthin content of germinable diatoms summed for all species, assuming that 1 germinable unit consists of 1 cell, before $(0)$ and after $(\bullet)$ the spring bloom. Measurements below detection limit are not included $(n=16$ before spring bloom and $n=$ 26 after spring bloom). Line obtained by linear regression $(\mathrm{p}<$ 0.0001). $(\Delta)$ data from Stn 444 before spring bloom that were treated as outliners during regression. Results of log-log regressions: slope $=0.46$, constant $=-0.18, \mathrm{r}^{2}=0.36, \mathrm{n}=42$ $(\mathrm{p}<0.0001)$

recent papers, the pools of germinable planktonic diatoms have been quantified (Itakura et al. 1997, Hansen \& Josefson 2001). From these studies it appears, surprisingly, that the populations of planktonic diatoms buried in the marine sediments are of nearly the same size as the entire population in the overlying water column under bloom conditions. Sediment-trap studies in the same area as studied herein (Olesen 1993, Kiørboe et al. 1994) have shown that a substantial fraction of the flux during the spring bloom consists of intact diatom cells. By considering the number of diatoms present in the sediment, we now know that not only do diatoms survive descent through the water column, but they also survive subsequent burial in the sediment for at least some months. Before the spring bloom, the populations varied between 9000 and 287000 germinable units $\mathrm{cm}^{-2}$ in the study area. Such pool sizes support the idea that diatoms do survive for long periods in sediments, and that part of spring bloom input probably persists even until the following spring bloom. It is not possible to calculate the exact decay rates, as it is not known when these diatoms entered into the sediment. However, the populations must have been there for at least 3 to $4 \mathrm{mo}$, as an input of this size is unlikely to have occurred during the winter. It is likely that this pool originated to a great extent from the spring bloom in 2000 (or earlier), as it was composed of the typical spring bloom genera Thalassiosira, Chaetoceros, Skeletonema and Leptocylindrus. Although diatom blooms occasionally occur during summer, such blooms are much more likely to be grazed in the water column by zooplankton, which are abundant at this time of year (Kiørboe \& Nielsen 1994, Nielsen \& Kiørboe 1994). If these pools originated from the spring bloom input in 2000 and this input was of the same size as that in 2001, the reduction 1 yr later suggests a decay rate between 0.007 and $0.01 \mathrm{~d}^{-1}$ at the individual stations. This is the same decay rate as suggested by Hansen \& Josefson (2001) after their study of 11 stations in the Øresund. However, in accordance with the observations of Itakura et al. (1997), Hansen \& Josefson (2003) and Josefson \& Hansen (2003), we observed that the spore-forming species were more abundant before the spring bloom than after it. This suggests that the total diatom population in the sediment reduce over time as a result of different specific decay rates of spores and vegetative cells.

Overall, the present study has shown that there is a clear signal from the diatom spring bloom in the sediment in terms of a 10- to 100-fold increase in the sediment content of both pigments and viable diatoms. In fact, the spring bloom event is as evident in the sediment as in the water column. From our data, we are convinced that both pigments and viable diatoms arise from the same source, i.e. that most of the pool of chlorophyll $a$ and fucoxanthin is stored inside live planktonic diatoms. The data set revealed a significant positive correlation between the MPN of diatoms and the sediment pigment content, and both pigments occurred in the same ratio as observed in the diatom cultures. The total abundance of diatoms could generally account for the entire pool of both chlorophyll $a$ and fucoxanthin observed in the sediment. Josefson \& Hansen (2003) analyzed more than 176 paired observations of viable diatoms and pigments from coastal areas and came to the same conclusion. The characteristic seasonal changes in the pool of chlorophyll $a$ in surface sediments has previously been described (Kanneworff \& Christensen 1986, Sun et al. 1994, Gerino et al. 1998). In these studies, the measurements of chlorophyll did not lead to consensus about the exact sources of chlorophyll in the sediment. Attempts have been made to quantify the input from the chlorophyll profiles by models assuming steady-state over long time and certain mixing and decay rates (Sun et al. 1991). To our knowledge, no direct attempt has been made to quantify the input directly from the enrichment in the sediment during the spring bloom.

\section{Spatial heterogeneity}

To us, one of the most remarkable results of this study was the total lack of sedimentation of diatoma- 
ceous material at the 2 stations in the central Kattegat, P6 and 413. We sampled a total of 8 cores in this area after the spring bloom, and none showed any sign of enrichment by diatom material. Firstly, the pools of pigments and GU decreased at Stn 413 during the spring bloom, and at P6 the content of pigments and GU was so low that even had the entire pool originated from the spring bloom of 2001, the input would still be the lowest among the stations. Secondly, the taxonomic composition of diatoms at Stn P6 resembled that at the other stations before the spring bloom, with a dominance of spore-forming species. Finally, Stn 413 was the only station where the pigments became more evenly distributed with increasing depth after the spring bloom, and almost identical profiles were found at Stn P6. This is a very strong indication that there had been no recent input of diatom material. A constant or decreasing pool size could, theoretically, be a result of such input on the one hand and fast degradation on the other hand. However, such a scenario would be evidenced by low pigment content and steep sediment depth profiles, as described by models of sedimentpigment dynamics (Sun et al. 1991). Resuspension followed by advection could be another mechanism by which the material was removed from the sediment surface just after deposition. Such a mechanism is possible at Stn P6, where the water depth is $32 \mathrm{~m}$, but is less likely to have occurred at Stn 413, which is $55 \mathrm{~m}$ deep (Floderus 1988). There could have been sedimentation of non-pigment-containing phytoplankton carbon in this area, which would not have been detected in these measurements. This would mean that the spring bloom, at these 2 stations (P6 and 413) exclusively, was processed in the water column, resulting in sedimentation of degraded and non-pigment-containing material. This is also unlikely, as the zooplankton grazing potential is usually low during the spring bloom in the study area (Kiørboe \& Nielsen 1994, Nielsen \& Kiørboe 1994). We hypothesize that the water masses in the central Kattegat in 2001 were advected before bulk sedimentation took place, and were replaced by water masses from which the spring bloom had already settled out. This would also imply that other areas received more material than the average produced in the water column, just as the nitrogen budget at Stn 444 suggests. Such a scenario, whereby little or no sedimentation occurs in certain areas while other areas receive input from several water masses, agrees with observations of bulk sedimentation events occurring at the peak of spring blooms (Alldredge \& Gotschalk 1989, Olesen 1993, Kiørboe et al. 1994). It also agrees with predictions from models of the dynamics of spring bloom sedimentation (Jackson 1990, Kiørboe et al. 1994, Hansen et al. 1995). In order to cause uneven deposition 2 things are needed: advection and non-synchronisation of bulk sedimentation of the spring bloom in the different water masses.

\section{Budgets}

At the 5 stations sampled before and after the spring bloom, we calculated on average recovery of 24,64 or $202 \%$ (depending on whether we assessed the input from chlorophyll $a$, fucoxanthin or GU) of the potential spring bloom production in the sediment 1 to 2 mo after the bloom. There are several uncertainties involved in constructing such a budget. Part of the budget comprises the amount of nitrogen consumed in the water column during the spring bloom, which of course may vary according to the exact nitrogen concentration and the exact depth of the mixed layer. However, this is of minor importance, as the distribution of nitrogen is fairly homogenous. The most important source of error is the large-scale variance in the bulk input of phytoplankton as discussed above, e.g. had we placed all our stations in the central Kattegat we would have come to the conclusion that no sedimentation occurred at all. A spatial sampling strategy relative to the hydrographic regime is therefore critical in order to achieve a good representation of the amount of phytoplankton that settles out of the water column. A precise estimate of the input to the sediment at a specific location is probably a matter of increasing the number of replicates. As noted in 'Results', there are high variances between replicate cores. We hypothesize that this variance arises from the heterogeneous nature of marine sediments, whereby macrofaunal burrows and other depressions in the sediment surface may concentrate the phytoplankton input at certain areas, thereby creating spatial heterogeneity in scales of centimetres and decimetres. Another problem is that we are not certain about the exact nature of 1 'seeding unit' as this may consist of more than 1 cell (discussed in Hansen \& Josefson 2001). Our predictions of the pigment content in the sediment were based on the assumption that 1 germinable unit consisted of only 1 cell. We may have a scenario whereby 1 unit consists of $>1$ cell which, on the other hand, contain less pigments than growing cells. Differences in the pigment content between vegetative cells, resting cells and spores have been described by French \& Hargraves (1980) and Kuwata et al. (1993). If the cells contain less pigment than growing cells, then we have underestimated the input of diatom material on the basis of both pigment and diatom content. Furthermore, the MPN itself is a conservative estimate of the number of live cells (discussed by Harris et al. 1998 and Hansen \& Josefson 2001). It is important to note that there are no mechanisms which could cause an overestimate of the input 
as long as the input of organic material is expressed in terms of living diatoms, otherwise the cells would be losing significant amounts of organic material while living. To what extent the total input is underestimated we cannot evaluate. To do this a better spatial coverage of the area would be necessary, as we do not know how well the 5 stations represent the area as a whole. Based on the various measurements we can only conclude that the input of live diatom biomass is at least in the same order of magnitude as the spring bloom production. However, considering that we have consistently presented conservative estimates of the input, we hypothesize that the input of live diatoms is quantitatively the most important input from the water column during the spring bloom. The recovery rate of pigments agree, with a similar comparison based on 11 stations in sediment in the Sound in June 1999 (Hansen \& Josefson 2001). The total abundance of diatoms after the spring bloom in our study also agrees with the levels observed in the Skagerrak-Kattegat frontal zone in May 2000 (Josefson \& Hansen 2003). The rest of the potential production is that part of the production that is remineralized by heterotrophic activity in the water column and does not sink out of the water column within 1 to 2 mo after the spring bloom. It also includes the amount of material that sinks in the form of dead material and material that is no longer recognizable as specific pigments. Finally, a part of the spring bloom input is processed in the sediment in the period between its arrival at the sediment and the sampling of the cores. Assuming a decay rate of $0.007 \mathrm{~d}^{-1}$, then about $20 \%$ of the input would have disappeared by the time of our second sampling cruise.

To quantify the input to the sediment, the recent works of Itakura et al. (1997) and Hansen \& Josefson (2001) have identified 2 important aspects: (1) there are markers which specifically relate to the pelagic input during the spring bloom, e.g. fucoxanthin and certain pelagic diatom species; (2) the diatoms survive relatively long periods in the sediment (Itakura et al. 1997, Hansen \& Josefson 2001), which means that the signal of the spring bloom remains in the sediment for some months after the spring bloom itself. Herman et al. (2001) suggested that the sea floor should be regarded as the 'ultimate sediment trap' in studies of input to the benthic ecosystem. In this context, analysis of pigments and diatoms in sediment cores can potentially be used directly to quantify the flux of diatom material during the spring bloom. Our measurements give an exclusive estimate of input of organic material bound in diatom biomass and, at the same time, a minimum estimate of the amount of diatoms that escapes degradation in the water column. Although material of other origin arrives at the sediment and although we do not know the total input, this 'recognizable' fraction appears to be very important as it is in the same order of magnitude as the potential new production in the water column. To obtain an estimate of the organic input to the benthic ecosystem, it is obvious that the use of sediment traps provides estimates of the total carbon flux as well as its elemental composition. However, there are drawbacks, as the vertical flux measured at certain depths is not necessarily the same as the input to the sediment, as indicated by some indirect comparisons (Graf et al. 1983, Rydberg et al. 1990). Resuspension may interfere with the measurements and, because there is a large pool of viable diatoms present in the sediment, microscopy is no guarantee that the 2 sources of material can be distinguished. We observed patchiness in the deposition of material, and such a phenomenon is difficult to account for in sediment trap studies, as this would demand many resources to operate sediment traps at several stations simultaneously. Because the diatoms degrade so slowly, they serve as perfect indicators of the distribution of the spring bloom input which, by simple means, can be mapped over a fairly long period after the spring bloom is over. A more exact picture of spring bloom sedimentation in terms of carbon requires a better understanding of the exact size of the germinable units of pelagic diatoms as well as the specific pigment content of resting cells and spores in the sediment. A more precise estimate of the flux of 'non-diatom' carbon associated with diatomaceous marine snow is necessary. In this respect, sediment-trap measurements and studies of diatom accumulations in the sediment would be complementary.

Acknowledgements. This work has been supported by an internal NERI-contract for the build-up of modelling competence, The National Environmental Monitoring Programme in Denmark, and the research is funded as part of the sharedcost research project KEYCOP (contract no. MAS3-CT970148) by the key action 'Sustainable Marine Ecosystems' of the EU RTD Programme 'Environment and Sustainable Development'; it forms part of the ELOISE projects cluster. We are also thankful to S. Lundsteen for providing sediment cores from the Arkona Sea, Femer Belt and The Great Belt, and we greatly appreciate the technical assistance provided by B. L. Møller, J. Damgaard and K. Sauerberg. Thanks to 3 anonymous referees for constructive comments which improved the manuscript.

\section{LITERATURE CITED}

Ærtebjerg G (2001) Monitoring Cruise with R/V Gunnar Thorson in the Sound, Kattegat, Skagerrak, North Sea and Arkona Sea. Cruise no 201,5-15 February 2001, Cruise Report. National Environmental Research Institute, Roskilde, available at: www.dmu.dk/1_om_dmu/2_afdelinger/ 3_hav/CruiseReports/index.htm

Alldredge AL, Gotschalk GC (1989) Direct observation of mass flocculation of diatom blooms: characteristics, set- 
tling velocities and formation of diatom aggregates. DeepSea Res 26:159-171

Anonymous (2001) Cruise report, R/V 'A. v. Humbolt' No. 44/01/03. Baltic Sea Research Institute, University of Rostock, Rostock-Warnemünde

Baker ET, Milburn HB, Tennant DA (1988) Field assessment under varying flow conditions. J Mar Res 46:573-592

Bråten S, Jensen C (eds) (2002) Vestlige Kattegat. Vestlige Kattegat og tilstødende fjorde 2001 tilstand og udvikling. Nordjyllands Amt 2002, Aalborg

Buffan-Dubau E, Carman KR (2000) Extraction of benthic microalgal pigments for HPLC analyses. Mar Ecol Prog Ser 204:293-297

Davis J M, Payne R (1984) Supply of organic matter to the sediment in the northern North Sea during a spring phytoplankton bloom. Mar Biol 78:315-324

Floderus S (1988) On the spatial distribution of wave impact at the Kattegat seabed. Geogr Ann 70A (3):269-272

French FW, Hargraves PE (1980) Physiological characteristics of planktonic diatom resting spores. Mar Biol Lett 1: 185-195

Fyns Amt (2002) Kystvande 2001. Vandmiljøovervågning Natur- og vandmiljøafdelingen. Fyns Amt, Odense

Garrison D L (1981) Montery Bay Phytoplankton. II. Resting spores cycles in coastal marine diatom populations. J Plankton Res 3:137-156

Gerino M, Aller RC, Lee C, Cochran JK, Aller JY, Green MA, Hirschberg D (1998) Comparison of different tracers and methods used to quantify bioturbation during a spring bloom: 234-thorium, luminophores and chlorophyll a. Estuar Coast Shelf Sci 46:531-547

Graf G, Bengtsson W, Diesner U, Schultz R, Theede H (1982) Benthic response to sedimentation of a spring phytoplankton bloom: process and budget. Mar Biol 67:201-208

Graf G, Schulz R, Peinert R, Meyer-Riel LA (1983) Benthic response to sedimentation events during autumn to spring at a shallow-water station in the Western Kiel Bight. Mar Biol 77:235-246

Hansen JLS, Josefson AB (2001) Pools of chlorophyll and live planktonic diatoms in aphotic marine sediments. Mar Biol 139:289-299

Hansen JLS, Timm U, Kiørboe T (1995) Adaptive significance of phytoplankton stickiness with emphasis on the diatom Skeletonema costatum. Mar Biol 123:667-676

Hansen PJ (1989) The red tide dinoflagellate Alexandrium tamerensis: effects on behaviour and growth of the tintinnid cilliates. Mar Ecol Prog Ser 53:105-116

Harris ASD, Jones KJ, Lewis J (1998) An assessment of the accuracy and reproducibility of the most probable number MPN technique in estimating numbers of nutrient stressed diatoms in sediments samples. J Exp Mar Biol Ecol 231: $21-30$

Herman P, Soetaert K, Middelburg JJ, Heip C and 5 others (2001) The seafloor as the ultimative sediment trapusing sediment properties to constrain benthic pelagic exchange processesat the Goban spur. Deep-Sea Res Part II 48:3245-3264

Itakura S, Imai I, Itoh K (1997) 'Seed bank' of coastal planktonic diatoms in bottom sediments of Hiroshima Bay, Seto Inland Sea, Japan. Mar Biol 128:497-508

Jackson GA (1990) A model of the formation of marine algal flocs by physical coagulation processes. Deep-Sea Res 37: $1197-1211$

Josefson AB, Hansen JLS (2003) Quantifying plant pigment and live planktonic diatoms in aphotic sediments of Scandinavian coastal waters confirms major route in the pelagic-benthic coupling. Mar Biol (in press)
Kanneworff E, Christensen H (1986) Benthic community respiration in relation to sedimentation in the Øresund. Ophelia 26:269-284

Kanneworff E, Nicolaisen W (1973) The Haps, a frame supported bottom corer. Ophelia 10:119-129

Kiørboe T, Nielsen TG (1994) Regulation of zooplankton biomass and production in a temperate, coastal ecosystem. 1. Copepods. Limnol Oceanogr 39:493-507

Kiørboe T, Lundsgaard C, Olesen M, Hansen JLS (1994) Aggregation and sedimentation processes during a spring phytoplankton bloom: a field experiment to test coagulation theory. J Mar Res 52:297-323

Kristiansen S, Farbrot T, Naustvoll LJ (2001) Spring bloom nutrient dynamics in the Oslofjord. Mar Ecol Prog Ser 219: 41-49

Kuwata A, Hama T, Takahashi M (1993) Ecophysiological characterization of two life forms, resting spores and resting cells of a marine planktonic diatom, Chaetoceros pseudocurvisetus, formed under nutrient depletion. Mar Ecol Prog Ser 102:245-255

Lewis J, Harris ASD, Jones KJ, Edmonds RL (1999) Long-term survival of marine planktonic diatoms and dinoflagellates in stored sediment samples. J Plankton Res 21:343-354

Lopez GR, Levinton JS (1987) Ecology of deposit-feeding animals in marine sediments. Q Rev Biol 62:235-260

Mantoura RFC, Llewellyn CA (1983) The rapid determination of algal chlorophyll and carotenoid pigments and their breakdown products in natural waters by reverse-phase high-performance liquid chromatography. Anal Chim Acta 151:297-314

Nielsen TG, Kiørboe T (1994) Regulation of zooplankton biomass and production in a temperate, coastal ecosystem. 2. Ciliates. Limnol Oceanogr 39(3):508-519

Olesen M (1993) The fate of an early diatom bloom in the Kattegat. Ophelia 37:51-66

Olesen M, Lundsgaard C (1995) Seasonal sedimentation of autochtonous material from the euphotic zone of a coastal system. Estuar Coast Shelf Sci 41:475-490

Passow U (1991) Species-specific sedimentation and sinking velocities of diatoms. Mar Biol 108:449-455

Platt T, Subba Rao DV, Smith JC, Li WK, Irwin B, Horne EPW, Sameoto DD (1983) Photosynthetically competent phytoplankton from the aphotic zone of the deep ocean. Mar Ecol Prog Ser 10:105-110

Reigstad M, Wassmann P, Ratkova T, Arashkevich E, Pasternak A, Øygarden S (2000) Comparison of the spring time vertical export of biogenic matter in three northern Norwegian fjords. Mar Ecol Prog Ser 201:73-89

Riebesell U (1991) Particle aggregation during a diatom bloom. II. Biological aspects. Mar Ecol Prog Ser 69: 281-291

Rydberg L, Edler L, Floderus S, Graneli W (1990) Interactions between supply of nutrients, primary production, sedimentation and oxygen consumption in SE Kattegat. Ambio 19(3):134-141

Smayda T, Mitchell-Innes B (1974) Dark survival of autotrophic, planktonic marine diatoms. Mar Biol 25: 195-202

Smetacek VS (1980) Annual cycles of sedimentation in relation to plankton ecology in the western Kiel Bight. Ophelia 1(Suppl):65-76

Smetacek VS (1985) Role of sinking in diatom life-history cycles: ecological, evolutionary and geological significance. Mar Biol 84:239-251

Strickland JDH, Parsons TR (1972) A pratical handbook of seawater analysis, 2nd edn. Bull Fish Res Board Can 167

Sun MY, Aller RC, Lee C (1991) Early diagenesis of chloro- 
phyll-a in Long Island Sound sediments: a measure of carbon flux and particle reworking. J Mar Res 49:379-401

Sun MY, Aller RC, Lee C (1994) Spatial and temporal distribution of sedimentary chloropigments as indicators of benthic processes in Long Island Sound. J Mar Res 52: 149-176

Tallberg P, Heiskanen AS (1998) Species-specific phytoplankton sedimentation in relation to primary production along an inshore-offshore gradient in the Baltic Sea. J Plankton Res 20:2053-2070

Thorstensson B (2001) Cruise report from R/V Argos, cruise May 5-12 2001, Oceanographical Laboratory, Swedish Meterological and Hydrographical Institute, available at: www.smhi.se.sgn0102/nodc

Editorial responsibility: Otto Kinne (Editor),

Oldendorf/Luhe, Germany
Tiselius P, Kuylenstierna M (1996) Growth and decline of a diatom spring bloom: phytoplankton species composition, formation of marine snow and the role of heterotrophic dinoflagellates. J Plankton Res 18:133-155

Trimmer M, Gowen RJ, Stewart BM, Nedwell DB (1999) The spring bloom and its impact on benthic mineralisation rates in western Irish Sea sediments. Mar Ecol Prog Ser 185:37-46

Wassmann P (1991) Dynamics of primary production and sedimentation in shallow fjords and pools of western Norway. Oceanogr Mar Biol Annu Rev 29:87-154

Utermöhl H (1958) Zur Vervollkommnung der quantitativen Phytoplankton Methodik. Mitt Int Ver Theor Agnew Limnol 9:1-38

Submitted: March 18, 2002; Accepted: October 15, 2002

Proofs received from author(s): January 17, 2003 